\title{
ResearchArticle
}

\section{Effect of salinity on germination and seedling growth of green gram varieties}

\author{
M. PRAKASH
}

\section{SUMMARY}

Salinity tolerance is one of the important abiotic stresses that damages crop growth. In order to study the effect of saline on germination and seedling attributes, four cultivated varieties of greengram were subjected with five levels of salinity viz., 0, 4, 8 and $12 \mathrm{ds} / \mathrm{m}$. Genotypic variation was observed for germination and seedling characters among the varieties. The experimental results revealed that with increase in salinity levels, greater reduction was observed for all the parameters. Germination per cent, seedling length, shoot, root and total dry matter production, seed vigour and salt tolerance index were found reduced in all the varieties studied with more reduction at higher salinity (12 ds/m) level rather than other lower salinity levels and shoot root ratio was found increased with increase in salinity.

Key Words : Green gram, Salinity, Germination, Seedling characters

How to cite this article : Prakash, M. (2017). Effect of salinity on germination and seedling growth of green gram varieties. Internat. J. Plant Sci., 12 (1): 79-84, DOI: 10.15740/HAS/IJPS/12.1/79-84.

Article chronicle : Received : 14.08.2016; Revised : 29.11.2016; Accepted : 25.12.2016

\section{AUTHOR FOR CORRESPONDENCE}

M. PRAKASH, Department of Genetics and Plant Breeding, Faculty of Agriculture, Annamalai University, ANNAMALAINAGAR (T.N.) INDIA

Email: geeth_prakash@yahoo.co.in 